\title{
Telomere shortening impairs organ regeneration by inhibiting cell cycle re-entry of a subpopulation of cells
}

\author{
A.Satyanarayana, S.U.Wiemann, J.Buer ${ }^{1,2}$, \\ J.Lauber ${ }^{2}$, K.E.J.Dittmar ${ }^{2}$, T.Wüstefeld, \\ M.A.Blasco ${ }^{3}$, M.P.Manns and K.L.Rudolph ${ }^{4}$ \\ Department of Gastroenterology, Hepatology and Endocrinology \\ and ${ }^{1}$ Department of Microbiology, Medical School Hannover, \\ Carl-Neuberg-Straße 1, D-30625 Hannover, ${ }^{2}$ Department of Cell \\ Biology, GBF, Germany and ${ }^{3}$ Department of Oncology, Canto Blanco, \\ Madrid, Spain \\ ${ }^{4}$ Corresponding author \\ e-mail: Rudolph.Lenhard@Mh-Hannover.de
}

Telomere shortening limits the regenerative capacity of primary cells in vitro by inducing cellular senescence characterized by a permanent growth arrest of cells with critically short telomeres. To test whether this in vitro model of cellular senescence applies to impaired organ regeneration induced by telomere shortening in vivo, we monitored liver regeneration after partial hepatectomy in telomerase-deficient mice. Our study shows that telomere shortening is heterogeneous at the cellular level and inhibits a subpopulation of cells with critically short telomeres from entering the cell cycle. This subpopulation of cells with impaired proliferative capacity shows senescence-associated $\beta$-galactosidase activity, while organ regeneration is accomplished by cells with sufficient telomere reserves that are capable of additional rounds of cell division. This study provides experimental evidence for the existence of an in vivo process of cellular senescence induced by critical telomere shortening that has functional impact on organ regeneration.

Keywords: cell cycle/DNA damage/ $\mathrm{G}_{1} / \mathrm{S}$ arrest/organ regeneration/senescence

\section{Introduction}

Telomeres are specialized nucleoprotein structures at the end of eukaryotic chromosomes (Blackburn, 1991). Loss of telomeric DNA via the end replication problem limits the proliferative capacity of primary cells in vitro at the stage of cellular senescence (Harley et al., 1990; Yu et al., 1990; Wright and Shay, 1992; Allsopp et al., 1995). Cells cannot proliferate beyond the senescence checkpoint unless the senescence pathway which is guarded by p53 and $\mathrm{Rb}$ is experimentally perturbed (Shay et al., 1991; Bond et al., 1996; Vaziri and Benchimol, 1996; Jarrard et al., 1999; Bringold and Serrano, 2000; Smogorzewska and de Lange, 2002). Experimental proof for the telomere hypothesis of 'cell aging' has come from studies showing that the ectopic expression of telomerase immortalizes primary human fibroblasts (Bodnar et al., 1998).
In humans, telomere shortening has been demonstrated in various tissues during aging (Lindsey et al., 1991; Vaziri et al., 1993, 1994; Allsopp et al., 1995; Chang and Harley, 1995) and in chronic diseases of elevated cell turnover (Kitada et al., 1995; Ball et al., 1998; Boultwood et al., 2000; Effros, 2000; Wiemann et al., 2002), and some of the recent studies have reported increased senescence-associated $\beta$-galactosidase activity in aged human skin (Dimri et al., 1995) and liver cirrhosis (Paradis et al., 2001; Wiemann et al., 2002). These data have fueled the debate that cellular senescence induced by telomere shortening might impact on regeneration of tissues and organs during aging and chronic high-turnover diseases. Experimental support for the telomere hypothesis of impaired organ regeneration during aging and chronic diseases has come from studies in telomerase-deficient mice $\left(\mathrm{mTERC}^{-/-}\right)$. Late-generation $\mathrm{mTERC}^{-/-}$mice with critically short telomeres show defects in homeostasis of highly proliferative organs (Lee et al., 1998) and these organ systems are affected by premature aging phenotypes (Herrera et al., 1999; Rudolph et al., 1999). In addition, liver regeneration was impaired in $\mathrm{mTERC}^{-/-}$mice in different model systems of liver regeneration (Rudolph et al., 2000). First, in response to partial hepatectomy $(\mathrm{PH})$, liver mass restoration was delayed and hepatocytes showed signs of telomere dysfunction (anaphase bridges) and a suppressed progression through the $\mathrm{G}_{2} / \mathrm{M}$ stage of the cell cycle (Rudolph et al., 2000). Secondly, in a model of acute liver failure, telomere shortening correlated with decreased hepatocyte proliferation and increased hepatocyte apoptosis. Finally, in response to chronic organ damage, the impaired organ regeneration in mTERC $^{-/-}$ mice results in a premature development of progressive disease stages such as liver cirrhosis (Rudolph et al., 2000) and colitis ulcerosa (J.Wedemeyer and K.L.Rudolph, unpublished data) - diseases in humans that are characterized by critical telomere shortening (Kinouchi et al., 1998; Wiemann et al., 2002).

The phenotype of impaired organ regeneration in mTERC $^{-1-}$ mice has been linked to the prevalence of critically short telomeres (Hemann et al., 2001), and the cell cycle inhibitor p53 was identified as mediating the adverse effects of telomere shortening (Chin et al., 1999). A current hypothesis is that critical telomere shortening leads to telomere dysfunction and activates DNA damage responses resulting in cell cycle arrest and/or apoptosis, as has been demonstrated in primary cell lines entering senescence in vitro. Since the replicative lifespans of subclones of a given cell line show high variability depending on the initial telomere length of individual subclones prior to expansion, it has been postulated that telomere length at the cellular level determines whether a cell enters senescence or continues to proliferate (Allsopp and Harley, 1995). Our study explores whether this model 
applies to the impaired regenerative capacity of organ systems in vivo by analyzing the cellular responses to $\mathrm{PH}$ in late-generation $\mathrm{mTERC}^{-/-}$mice and $\mathrm{mTERC}^{+/+}$controls. We present direct evidence for induction of cellular senescence by critical telomere shortening at the cellular level in vivo and its impact on organ regeneration.

\section{Results}

Telomere shortening limits the number of cells participating in organ regeneration

The resting liver is a mitotically inactive organ with over $95 \%$ of the cells in the $G_{0}$ stage of the cell cycle. In

A

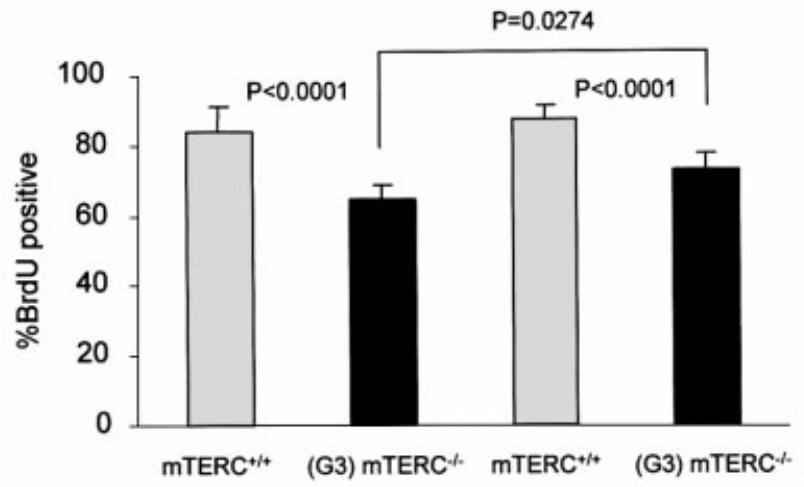

B

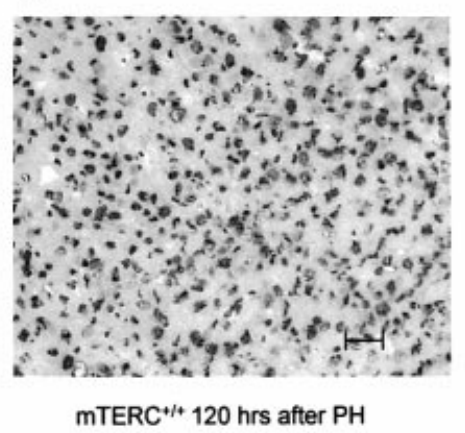

C

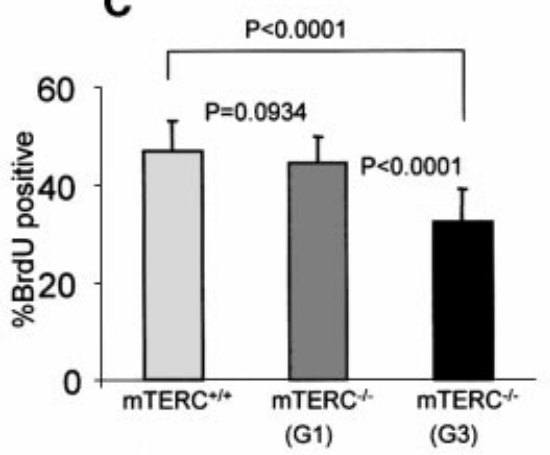

120 hrs after $\mathrm{PH}$

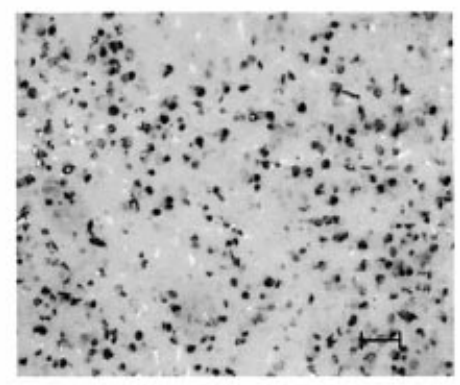

G3 mTERC $* 120$ hrs after PH

D

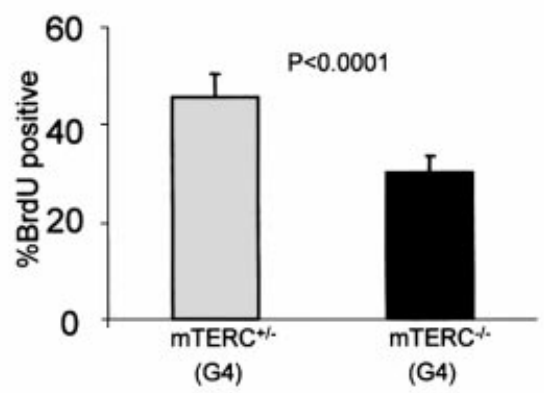

Fig. 1. Telomere shortening inhibits a subpopulation of cells from participating in liver regeneration. The percentage of liver cells incorporating BrdU in response to PH under continuous BrdU labeling is higher in mTERC ${ }^{+/+}$than in $\mathrm{G}_{3}$ mTERC $^{-/-}$mice. (A) Rate of BrdU-labeled liver cells $72 \mathrm{~h}$ after $\mathrm{PH}\left[83.83 \pm 7.44 \%\right.$ in $\mathrm{mTERC}^{+/+}(n=5)$ versus $64.5 \pm 4.28 \%$ in $\left.\mathrm{G}_{3} \mathrm{mTERC}^{-/-}(n=5), p<0.0001\right]$ and $120 \mathrm{~h}$ after PH $\left[86.96 \pm 4.33 \mathrm{in} \mathrm{mTERC}^{+/+}\right.$ $(n=5)$ versus $72.30 \pm 5.45 \%$ in $\mathrm{G}_{3}$ mTERC $\left.^{-/}(n=5), p<0.0001\right]$. (B) Representative photographs of BrdU staining pattern in $\mathrm{mTERC}^{+/+}$and $\mathrm{G}_{3}$ mTERC $^{-/-}$mice $120 \mathrm{~h}$ after PH under continuous BrdU infusion (bar, $150 \mu \mathrm{m}$ ). (C) Percentage of cells incorporating BrdU at the first peak stage of S-phase $(48 \mathrm{~h}$ after $\mathrm{PH})$ under $2 \mathrm{~h}$ of BrdU pulse labeling: $47.03 \pm 6.33 \%$ in $\mathrm{mTERC}^{+/+}(n=5)$ versus $44.45 \pm 5.26 \% \mathrm{G}_{1} \mathrm{mTERC}^{---}(n=5, p=$ $0.0934)$ and $32.31 \pm 6.65 \% \mathrm{G}_{3}$ mTERC $^{-l-}(n=5, p<0.0001)$. A significant reduction in the BrdU index is evident in $\mathrm{G}_{3} \mathrm{mTERC}^{-/-}$mice, whereas $\mathrm{G}_{1}$ mTERC $^{-/-}$mice show a similar rate of BrdU-positive liver cells compared with mTERC ${ }^{+/+}$mice, indicating that telomere length but not lack of telomerase impacts on the number of cells participating in organ regeneration. (D) Percentage of cells incorporating BrdU at the first peak stage of S-phase (48 $\mathrm{h}$ after $\mathrm{PH})$ under $2 \mathrm{~h}$ of BrdU pulse labeling: $45.52 \pm 4.65 \%$ in $\mathrm{G}_{4} \mathrm{mTERC}^{+/-}(n=5)$ versus $29.90 \pm 3.25 \% \mathrm{G}^{2} \mathrm{mTERC}^{-/-}(n=5, p<$ 0.0001). $\mathrm{G}_{4} \mathrm{mTERC}^{+-}$mice show a rescue in the percentage of BrdU-positive cells, indicating that telomere stabilization by telomerase re-expression rescues suppression of cell cycle re-entry of a subpopulation of cells. 
response to $\mathrm{PH}$, liver cells re-enter the cell cycle in a highly synchronized fashion and regenerate lost mass by one to two rounds of replication within a week, thus representing a system in which somatic cell division regenerates organ mass without a direct need for a specific stem cell population (Fausto, 2000; Kountouras et al., 2001). To analyze the impact of telomere shortening on organ regeneration at the cellular level, continuous labeling of all the proliferating cells with 5-bromo$2^{\prime}$-deoxyuridine (BrdU) was performed in G3 mTERC $^{-1-}$ and mTERC $^{+/+}$controls until two rounds of replication (120 h after PH) had been completed. After both the first round (72 $\mathrm{h}$ after $\mathrm{PH})$ and the second round $(120 \mathrm{~h}$ after $\mathrm{PH})$ of DNA replication, the number of cells participating in liver regeneration was significantly reduced in $G_{3}$ mTERC $^{-/-}$mice compared with mTERC $^{+/+}$mice (Figure 1A and B). These data indicated that telomere shortening inhibited a subpopulation of liver cells from participating in organ regeneration.

Previous studies in late-generation $\mathrm{mTERC}^{-/-}$mice have shown that telomere shortening leads to defective regeneration and impaired organ homeostasis (Lee et al., 1998; Herrera et al., 1999; Rudolph et al., 1999, 2000). To test whether inhibited cell cycle entry of a subpopulation of cells in $\mathrm{G}_{3}$ mTERC $^{-/-}$mice is due to critical telomere shortening, we monitored liver regeneration in $G_{1}$ mTERC $^{-l-}$ mice (i.e. animals lacking telomerase activity but having long telomere reserves) (Blasco et al., 1997). $\mathrm{S}$-phase activity in response to $\mathrm{PH}$ peaks at $48 \mathrm{~h}$ after surgery. Two hours of pulse labeling with BrdU at this time point revealed similarly high rates of BrdU incorporation in $\mathrm{G}_{1}$ mTERC $^{-/-}$and $\mathrm{mTERC}^{+/+}$mice compared with a significantly lower rate in $\mathrm{G}_{3}$ mTERC $^{-/-}$mice (Figure 1C). In addition, telomere stabilization by telomerase re-expression in $\mathrm{G}_{4} \mathrm{mTERC}^{+/-}$mice, derived from a cross of $\mathrm{G}_{3}$ mTERC $^{-/-}$mice and mTERC $^{+/-}$mice (Samper et al., 2001), completely rescued the defective regenerative response following $\mathrm{PH}$, which was present in $\mathrm{G}_{4}$ mTERC $^{-/-}$littermates (Figure 1D). Together, these data indicated that the phenotype of a decreased population of cells entering the cell cycle during organ regeneration is due to telomere shortening, independent of telomerase per se, but can be rescued by telomere stabilization in mice with critically short telomeres.

\section{Critical telomere shortening at the cellular level blocks cell cycle re-entry of a subpopulation of liver cells in $\mathrm{G}_{3} \mathrm{mTERC}^{-/-}$mice}

A possible explanation for the inhibition of cell cycle reentry in a subpopulation of cells in $\mathrm{G}_{3} \mathrm{mTERC}^{--}$mice is that telomeres in cells of an organ system are heterogeneous, and that only cells with critically short dysfunctional telomeres are inhibited from entering the cell cycle. To test this hypothesis, telomere length was analyzed at the single-cell level using quantitative fluorescence in situ hybridization (qFISH) (Gonzalez-Suarez et al., 2000; Poon and Landsdorp, 2001) in combination with BrdU staining (Figure 2A-C). With this approach, it is possible to compare telomere lengths directly between liver cells participating in organ regeneration (BrdU positive) and liver cells inhibited from cell cycle re-entry (BrdU negative). In $\mathrm{mTERC}^{+/+}$mice, BrdU-positive and BrdUnegative liver cells $(120 \mathrm{~h}$ after $\mathrm{PH}$ and continuous labeling with BrdU) showed similar mean telomere fluorescence intensities (Figure 2D, E and $\mathrm{H}$ ). As expected, the overall telomere fluorescence intensity is lower in $\mathrm{G}_{3}$ mTERC $^{-/-}$mice than in $\mathrm{mTERC}^{+/+}$mice. Interestingly, however, within the liver of $\mathrm{G}_{3} \mathrm{mTERC}^{-/-}$ the telomere fluorescence intensity was significantly weaker in the subpopulation of cells inhibited from cell cycle re-entry (BrdU negative) than in the population of proliferating cells (BrdU positive) (Figure 2F-H). In addition to lower mean telomere fluorescence intensity, the non-proliferating cells also had lower minimum fluorescence intensities compared with the proliferating cells in $\mathrm{G}_{3} \mathrm{mTERC}^{-1-}$ mice (data not shown). The observation that the mean telomere fluorescence intensities between BrdU-positive and BrdU-negative cells $120 \mathrm{~h}$ after $\mathrm{PH}$ were similar in $\mathrm{mTERC}^{+/+}$mice indicates that BrdU staining and cell cycle stage did not interfere with hybridization and quantification of the telomeric probe at the telomeres. These data gave direct evidence that critically short telomeres at the cellular level limit the proliferative capacity of cells within an organ system.

\section{Non-proliferating cells with critically short telomeres in MTERC $^{-/}$are senescent}

A possible mechanism for inhibition of cell cycle re-entry in a subpopulation of cells is the induction of cellular senescence, which in primary human cells is induced after 50-70 cell doublings, first affecting subclones with critically short telomeres of a given cell line in vitro (Allsopp and Harley, 1995). To test directly whether the non-proliferating cells in $\mathrm{G}_{3} \mathrm{mTERC}^{-/}$entered senescence, senescence-associated (SA) $\beta$-galactosidase staining (Dimri et al., 1995) was conducted on liver samples $120 \mathrm{~h}$ after $\mathrm{PH}$ to compare directly the percentage of SA $\beta$-galactosidase-positive cells with the percentage of non-proliferating cells (BrdU negative). This method revealed significantly increased rates of senescent cells in $\mathrm{G}_{3}$ mTERC $^{-/-}$mice compared with $\mathrm{mTERC}^{+/+}$mice (Figure 3A and B). Even though SA $\beta$-galactosidase staining is widely used as a marker of senescence, it has been shown that false-positive results occur in vitro in cell cultures exposed to various stresses (Severino et al., 2000). To exclude unspecific non-senescence-related SA $\beta$-galactosidase staining, a co-staining combining BrdU staining with SA $\beta$-galactosidase staining was conducted. This co-staining revealed a strong coincidence of $\beta$-galactosidase activity with non-proliferating cells (BrdU negative) in $\mathrm{G}_{3} \mathrm{mTERC}^{-/-}$mice. Specifically, only $13 \pm 4.84 \%$ of the SA $\beta$-galactosidase-positive cells were BrdU positive, whereas $79 \pm 6.2 \%$ of the SA $\beta$-galactosidase-negative fraction of cells showed BrdU incorporation (Figure 3C).

To show directly that the SA $\beta$-galactosidase-positive cells in $\mathrm{G}_{3}$ mTERC $^{-1-}$ mice were inhibited from cell cycle re-entry by critically short telomeres, a co-staining combining SA $\beta$-galactosidase staining with telomeric qFISH was carried out. As anticipated from the above results, this analysis revealed significantly weaker telomere fluorescence intensities in SA $\beta$-galactosidase-positive cells than in SA $\beta$-galactosidase-negative cells in $\mathrm{G}_{3}$ mTERC $^{-/-}$mice (Figure $3 \mathrm{D}$ and $\mathrm{E}$ ). In contrast, $\mathrm{mTERC}^{+/+}$mice showed no difference in the telomere fluorescence intensity comparing SA $\beta$-galactosidase-positive and -negative cells. 
A

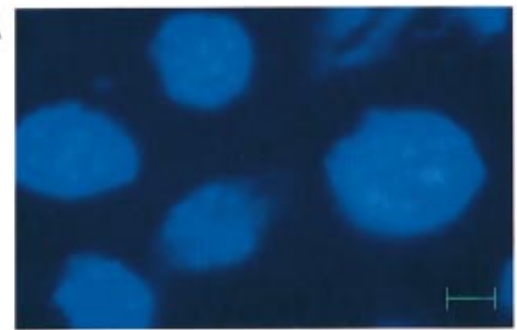

B

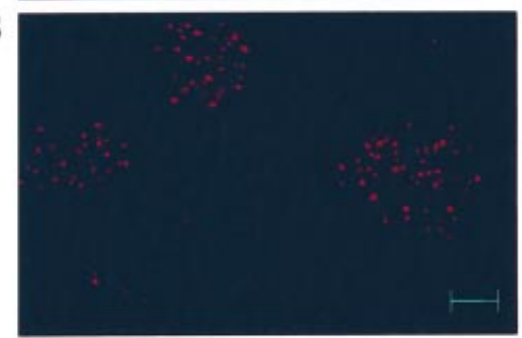

C

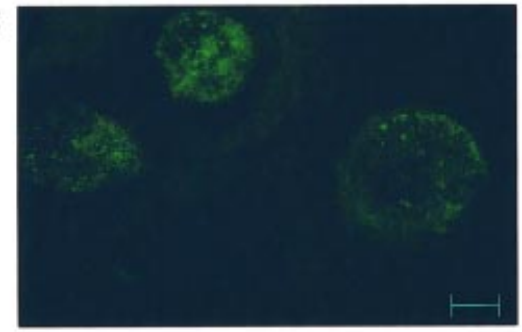

$\mathrm{H}$

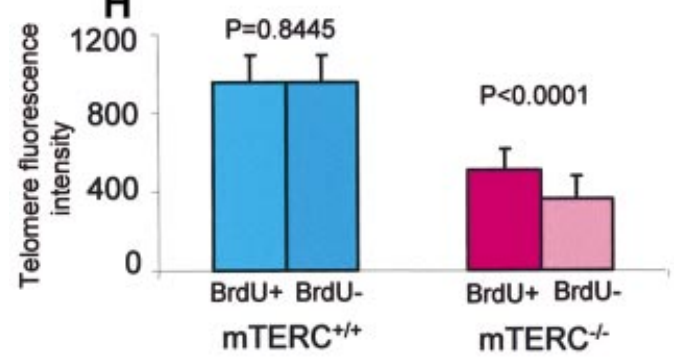

DAPI

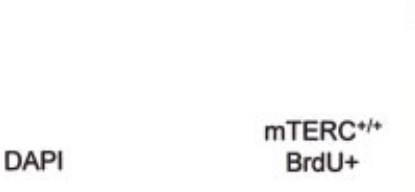

Anti-BrdU-

FITC

Суз-00-

$(\text { CCCTAA })_{3}$

mTERC
BrdU-

MTERC -1

BrdU+

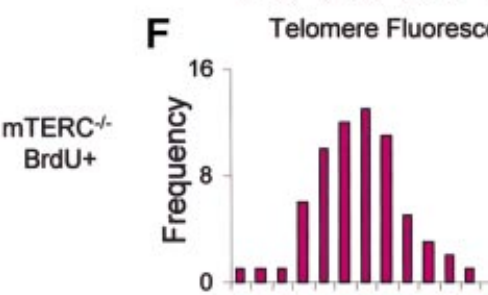

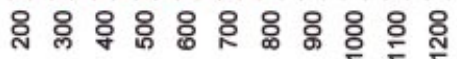

G

Telomere Fluorescence-intensity

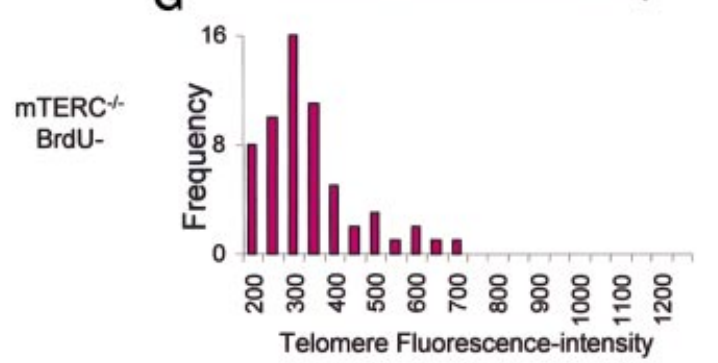

Fig. 2. Critical telomere shortening at the cellular level inhibits cell cycle re-entry of a subpopulation of cells. Telomere length analysis at cellular level by qFISH was combined with BrdU staining (A-C). (A) DAPI counterstaining. (B) qFISH with a telomere-specific probe Cy3-OO-(CCCTAA) 3 . (C) BrdU staining with anti-BrdU monoclonal antibody and FITC-conjugated secondary antibody. The liver samples from $120 \mathrm{~h}$ of continuous BrdU labeling after $\mathrm{PH}$ were used to measure and compare the telomere fluorescence intensities in BrdU-positive and BrdU-negative cells. In total, the fluorescence intensities of telomere spots were analyzed from $69 \mathrm{BrdU}$-positive and $54 \mathrm{BrdU}$-negative nuclei from mTERC ${ }^{+/+}(n=5)$, and $66 \mathrm{BrdU}^{-p}$ positive and $60 \mathrm{BrdU}$-negative nuclei from $\mathrm{G}_{3} \mathrm{mTERC}^{-/-}(n=5)$ mice. (D) Telomere fluorescence intensity of BrdU-positive cells in $\mathrm{mTERC}^{+/+}$mice. (E) BrdU-negative cells in mTERC ${ }^{+/+}$mice. (F) BrdU-positive cells in $\mathrm{G}_{3}$ mTERC $^{-/-}$mice. (G) BrdU-negative cells in $\mathrm{G}_{3} \mathrm{mTERC}^{-/-}$. (H) The mean telomere fluorescence intensities of BrdU-positive cells (952.53 \pm 144.19$)$ and BrdU-negative cells $(957.44 \pm 130.57)$ in $\mathrm{mTERC}^{+/+}$mice, and BrdUpositive cells $(509.65 \pm 101.30)$ and BrdU-negative cells $(364.94 \pm 116.45)$ in $\mathrm{G}_{3}$ mTERC $^{-/-}$mice.

Therefore, the low prevalence of SA $\beta$-galactosidasepositive cells in mTERC $^{+/+}$mice was independent of telomere shortening, possibly resembling the 'premature senescence' phenotype induced by mitogenic stimulation such as ras signaling (Serrano et al., 1997). Although interference of SA $\beta$-galactosidase staining or senescence per se with telomere probe hybridization and measurement during qFISH remains formally possible, the data showing similar telomere fluorescence intensity in SA $\beta$-galactosidase-positive and -negative liver cells of mTERC $^{+/+}$mice indicate that such interference did not occur.

The $\mathrm{Rb}$ and $\mathrm{p} 53$ pathways have been prominently associated with cellular senescence (Bond et al., 1996; Vaziri and Benchimol, 1996; Jarrard et al., 1999; Bringold and Serrano, 2000; Smogorzewska and de Lange, 2002).
To test for activation of these senescence pathways in mTERC $^{-1-}$ mice, Affimetrix oligonucleotide microarray analysis was carried out in duplicate comparing gene expression levels in quiescent liver and at the $G_{1} / S$ transition (30-36 $\mathrm{h}$ after $\mathrm{PH})$. This time point was chosen since most of the known senescence pathways are active at this transition point (Pang and Chen, 1994; Chen, 1997). We monitored gene expression changes between these two time points and compared the differentially regulated genes in $\mathrm{mTERC}^{+/+}$and $\mathrm{G}_{3}$ mTERC $^{-/-}$mice. This experiment identified 114 differentially expressed genes, 34 genes that were regulated in $\mathrm{mTERC}^{+/+}$but not $\mathrm{G}_{3}$ mTERC $^{-/-}$mice and 79 genes that were regulated in $\mathrm{G}_{3}$ mTERC $^{-/-}$mice but not mTERC $^{+/+}$mice (data not shown). The full dataset of this microarray experiment is accessible 

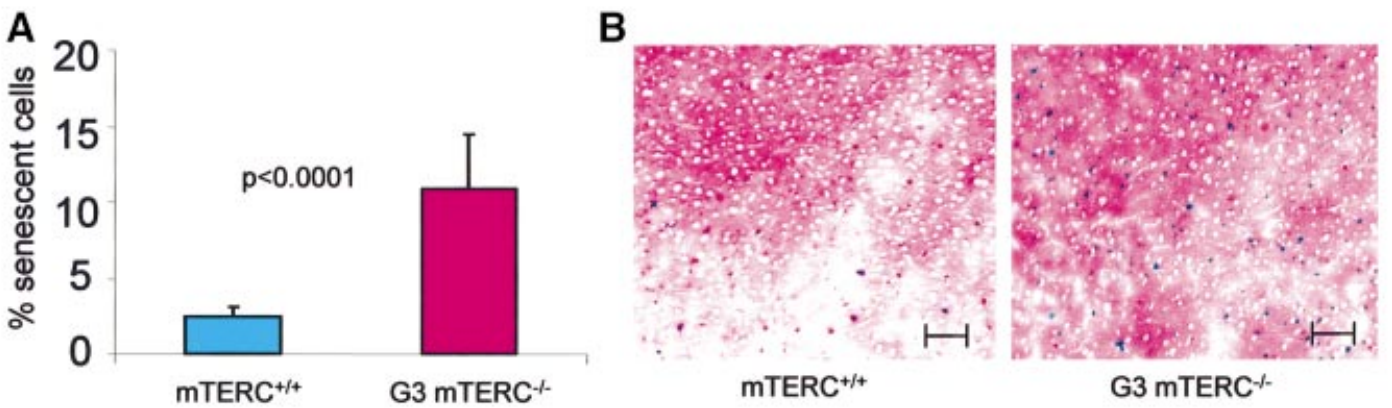

C
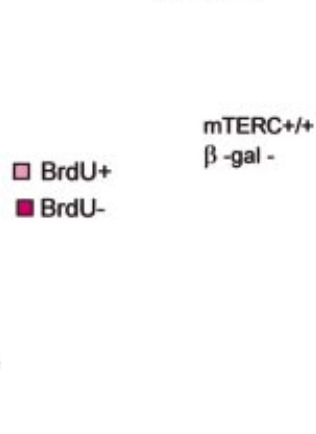

E
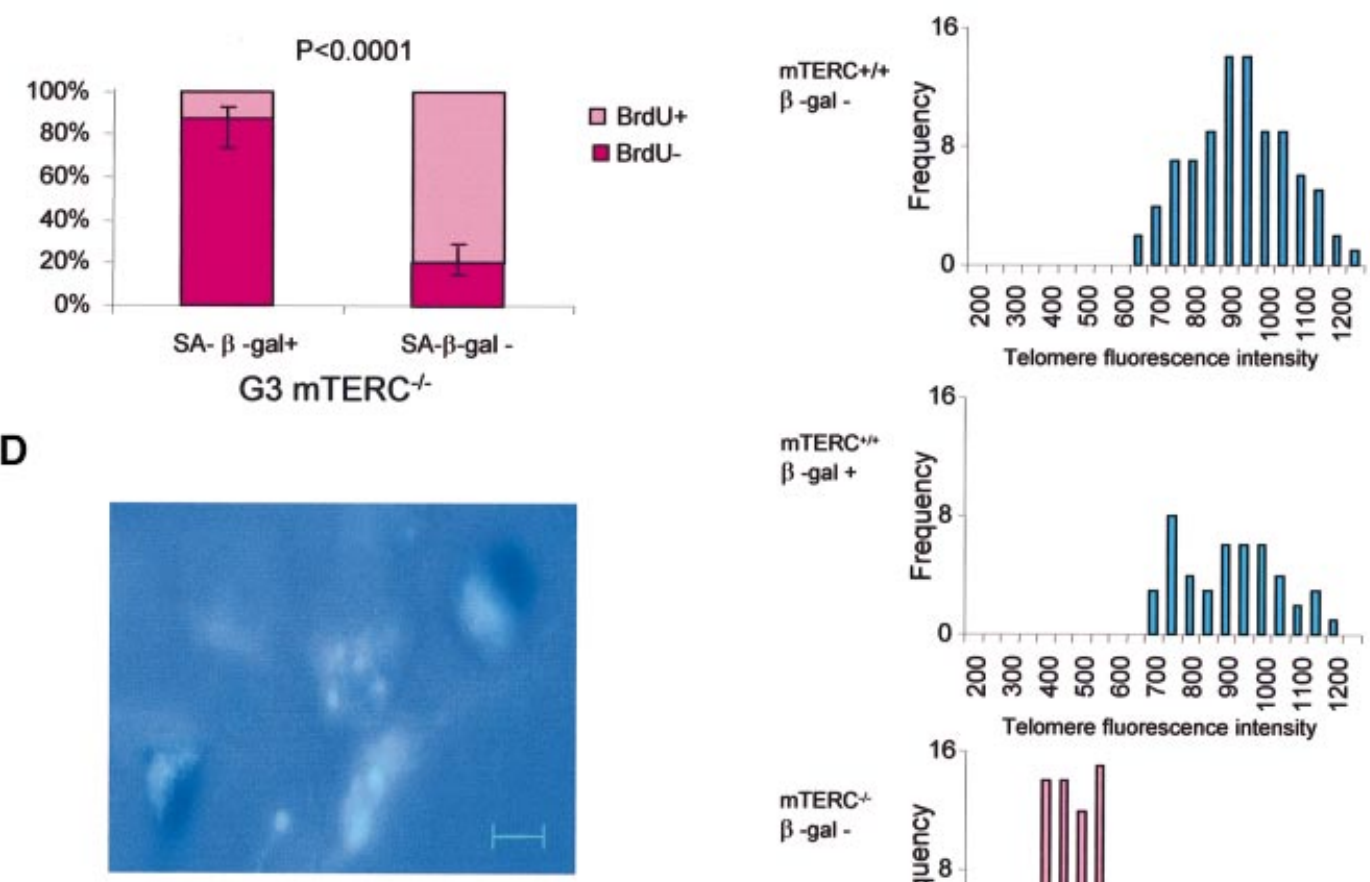

SA- $\beta$-gal

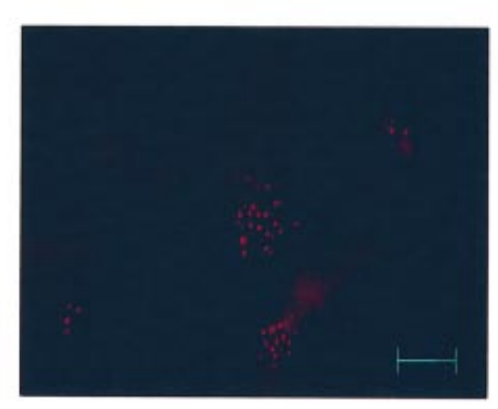

CY3-OO-(CССТAA)

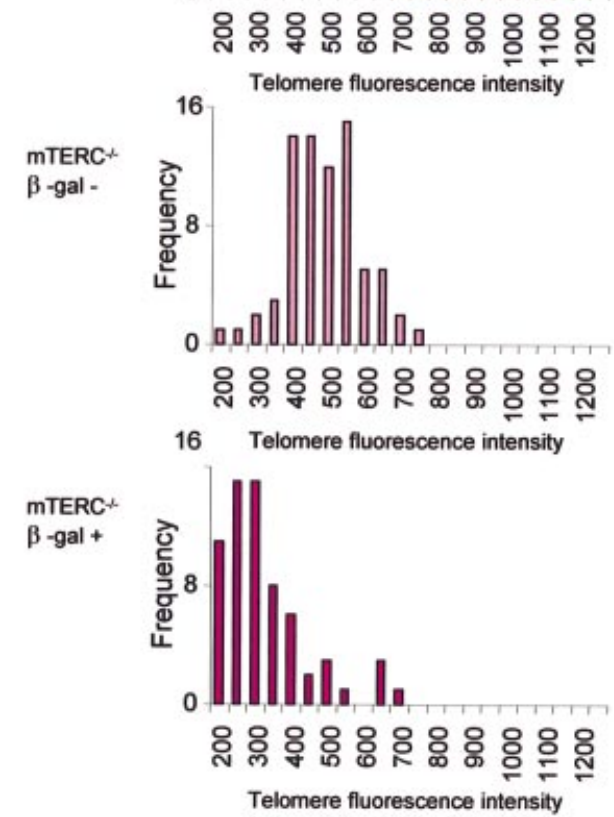

Fig. 3. Co-localization of SA $\beta$-galactosidase acitivity in non-proliferating cells with critically short telomeres. (A) SA $\beta$-galactosidase staining at pH 6 shows a higher number of positive cells in $\mathrm{G}_{3} \operatorname{mTERC}^{-/-}(n=5)$ mice $(10.83 \pm 3.61 \%)$ compared with mTERC ${ }^{+/+}(n=5)$ mice $(2.54 \pm 0.7 \%$, $p<0.0001)$. (B) Representative photographs of SA $\beta$-galactosidase-stained liver sections $\left(120 \mathrm{~h}\right.$ after PH) of mTERC $\mathrm{m}^{+/+}$and $\mathrm{G}_{3} \mathrm{mTERC}^{-/-} \mathrm{mice}(\mathrm{bar}$, $300 \mu \mathrm{m})$. (C) Co-localization of SA $\beta$-galactosidase activity in non-proliferating liver cells of $\mathrm{G}_{3} \mathrm{mTERC}^{-/-}$mice. Only $13 \pm 4.84 \%$ of the SA $\beta$-galactosidase-positive cells are BrdU positive, whereas $79 \pm 6.2 \%$ of the SA $\beta$-galactosidase-negative cells are BrdU positive. (D) Representative photograph of SA $\beta$-galactosidase and telomere probe co-staining showing that the fluorescent intensity of telomere spots is weaker in SA $\beta$-galactosidasepositive cells. (E) The frequencies of mean telomere fluorescence intensities in nuclei of (top to bottom) SA $\beta$-galactosidase-negative cells in mTERC $^{+/+}$, SA $\beta$-galactosidase-positive cells in $\mathrm{mTERC}^{+/+}$, SA $\beta$-galactosidase-negative cells in $\mathrm{G}_{3} \mathrm{mTERC}^{-/-}$and SA $\beta$-galactosidase-positive cells in mTERC $^{-1-}$. In total, the fluorescence intensities of telomere spots were analyzed from 89 SA $\beta$-galactosidase-negative cells $(963.10 \pm 130.65)$ and 46 SA $\beta$-galactosidase-positive cells $(937.30 \pm 135)$ from $\operatorname{mTERC}^{+/+}(n=5)$ and from $75 \mathrm{SA} \beta$-galactosidase-negative cells $(521.86 \pm 100.16)$ and 65

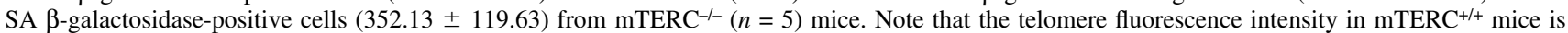
similar between SA $\beta$-galactosidase-positive and -negative cells, indicating that SA $\beta$-galactosidase staining did not interfere with telomere probe hybridization and measurement. 


\begin{tabular}{llllll}
\hline \multicolumn{6}{l}{ Table I. Differentially expressed cell cycle regulating genes at $\mathrm{G}_{0}-\mathrm{G}_{1} / \mathrm{S}$ transition in $\mathrm{G}_{3}$ mTERC $^{-/-}$mice } \\
\hline No. & Gene description & Symbol & $\Delta$ RT-PCR & Function & Gene bank \\
\hline 1 & Cyclin-dependent kinase inhibitor 1A, p21 & Cdkn1a & 6.02 & Senescence, DNA damage response, cell cycle regulation & Aw048937 \\
2 & Fas associated factor 1 & Fafl & -4.08 & Apoptosis & U39643 \\
3 & Growth arrest and DNA damage inducible & Gadd45g & 5.09 & DNA damage response, cell cycle arrest & Af055638 \\
4 & Krupple-like factor 4 & Klf4 & 5.77 & DNA damage response & U20344 \\
5 & Nucleobindin2 & Nucb2 & 12.9 & Cell cycle regulation, growth arrest & Aj222586 \\
6 & P87 Wee1 kinase & Wee1 & -5.93 & DNA damage response, cell cycle regulation & D30743 \\
7 & Polo-like kinase & Plk & 8.63 & DNA damage response, cell cycle regulation & Av305987 \\
8 & Protein kinase inhibitor $\mathrm{p}^{58}$ & Prkri & 3.60 & Growth regulation & U28423 \\
\hline
\end{tabular}

$\Delta$ is the fold change of gene expression.
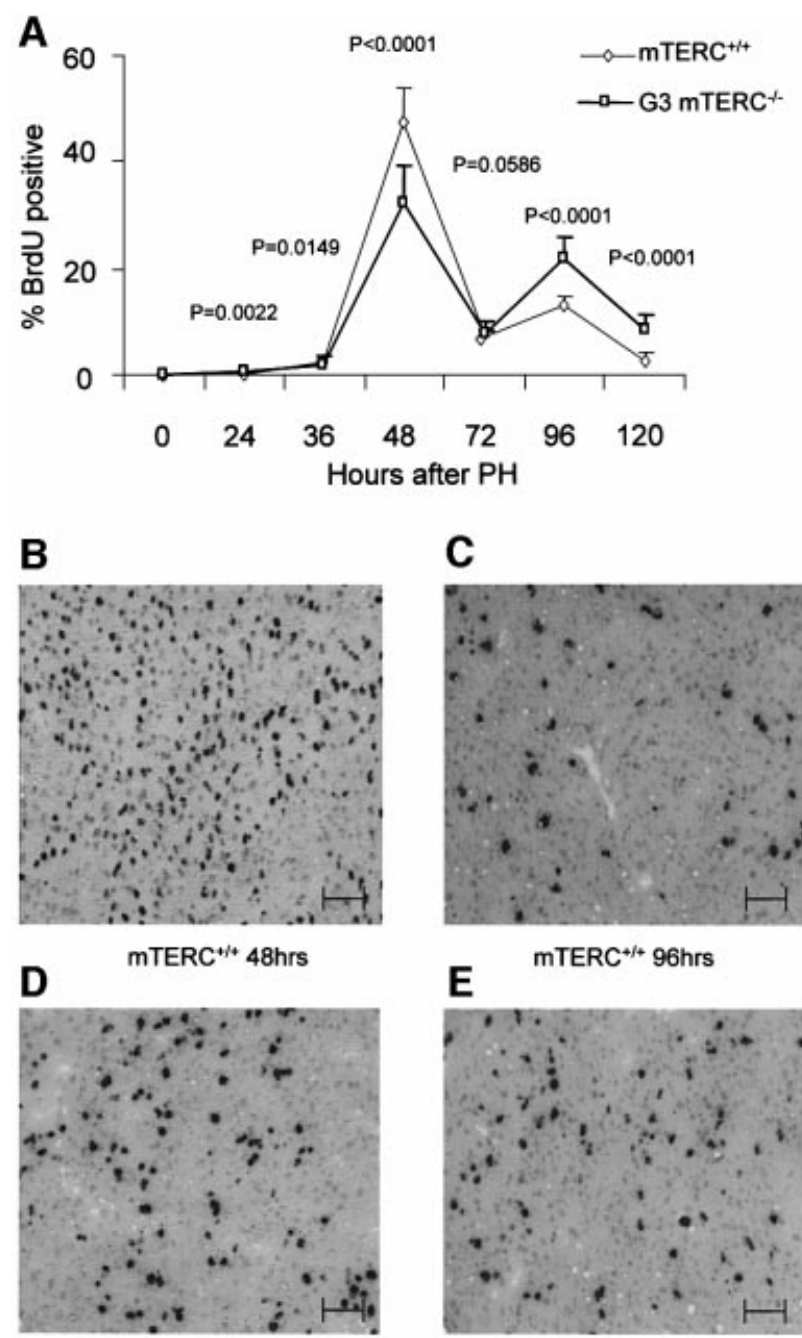

G3 mTERC $+48 \mathrm{hrs}$
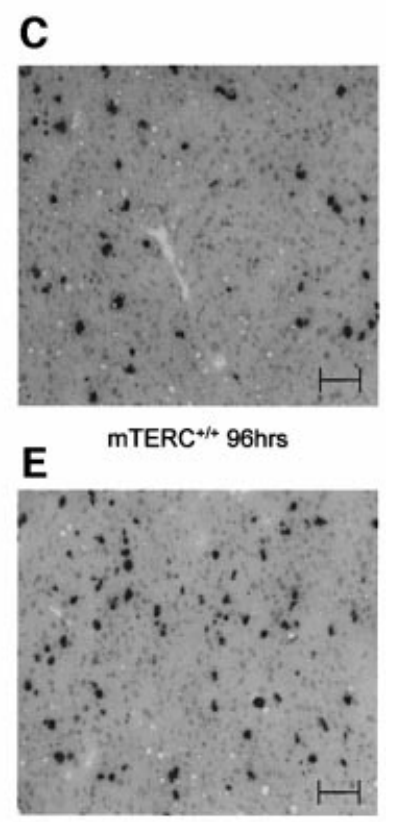

G3 mTERC ${ }^{+}$-96hrs

Fig. 4. Cells with sufficient telomere reserves compensate for impaired organ regeneration by an additional round of replication. (A) Percentage of BrdU-positive cells at different time points after PH in mTERC $\mathrm{C}^{+/+}$ and $\mathrm{G}_{3}$ mTERC $^{-1-}$ mice as determined by $2 \mathrm{~h}$ of BrdU pulse labeling. (B-E) Representative photographs of the BrdU staining pattern at the two peak stages of S-phase in $\mathrm{mTERC}^{+/+}$and $\mathrm{G}_{3}$ mTERC $^{-/-}$mice (bar, $150 \mu \mathrm{m}) . \mathrm{mTERC}^{+/+}$mice show a higher percentage of BrdU-positive cells $(47.03 \pm 6.33 \%, n=5)$ at the first-peak stage of S-phase $(48 \mathrm{~h}$ after $\mathrm{PH})$ compared with $\mathrm{G}_{3}$ mTERC $^{-/-}$mice $(32.31 \pm 6.65 \%, n=5$, $p<0.0001)$. In contrast, at the second-peak stage of S-phase $(96 \mathrm{~h}$ after $\mathrm{PH}), \mathrm{G}_{3} \mathrm{mTERC}^{-/}$mice show a higher percentage of BrdU-positive cells $(21.58 \pm 4.24 \%, n=5)$ compared with mTERC $^{+/+}$mice $(12.66 \pm 1.69 \%, n=5, p<0.0001)$.

in MIAME format online (www.gbf.de/array) under downloads (under Satyanarayana et al.: Table1, Table2 and ExperimentalDesign). From the differentially regulated genes in the microarray experiments comparing resting liver and regenerating liver $30-36 \mathrm{~h}$ after $\mathrm{PH}$ in mTERC $^{+/+}$mice and $\mathrm{G}_{3}$ mTERC $^{-/-}$mice, eight target genes which have a role in cell cycle regulation were chosen and their differential expression was confirmed by RT-PCR (Table I). The gene list include four downstream targets of p53 (p21, plk, Gadd45g and KLF-4) which were all upregulated in $\mathrm{G}_{3}$ mTERC $^{-/-}$mice; two of these genes ( $p 21$ and Gadd45g) have previously been related to replicative senescence and DNA damage response that leads to $\mathrm{G}_{1} / \mathrm{S}$ arrest (Dulic et al., 2000; Vairapandi et al., 2002).

To analyze the role of factors other than impaired cell cycle re-entry that could explain the decreased rate of proliferation in $\mathrm{G}_{3} \mathrm{mTERC}^{-/}$mice, we evaluated mitogenic signaling and apoptosis in this system. The most prominent mitogenic signal priming liver cells to reenter the cell cycle is interleukin 6 (IL-6) (Cressman et al., 1996; Li et al., 2001). Induction and peak levels of IL-6 in response to $\mathrm{PH}$ were similar in $\mathrm{mTERC}^{+/+}$and $\mathrm{G}_{3}$ mTERC $^{-/-}$mice (data not shown), indicating that impaired mitogen responses did not account for the defective liver regeneration in $\mathrm{G}_{3}$ mTERC $^{-/-}$mice. Apoptosis has been linked to impaired organ regeneration of highly selfrenewing organs in mTERC $^{-1-}$ mice (Lee et al., 1998) and is induced by telomere shortening in clonally regenerating hepatocytes in the setting of acute liver failure (Rudolph et al., 2000). We assessed the possible impact of apoptosis in our experimental system using the TUNEL assay. Following PH, TUNEL staining showed very low but similar rates of apoptosis in the liver of $\mathrm{mTERC}^{+/+}$and $\mathrm{G}_{3}$ mTERC $^{-/-}$mice (data not shown), suggesting that this process did not account for the differences in regenerative response. Given that apoptosis is predominantly present in the setting of telomere shortening coupled with extensive regenerative pressure in $\mathrm{mTERC}^{-/-}$mice (Lee et al., 1998; Rudolph et al., 2000), it seems possible that the limited apoptotic response to $\mathrm{PH}$ was indicative of the more moderate regenerative stress in this setting.

\section{Cells with sufficient telomere reserves in $G_{3}$ mTERC ${ }^{-/-}$mice compensate for impaired organ regeneration by an additional round of replication}

Synchronized liver regeneration in response to two-thirds $\mathrm{PH}$ takes approximately one and a half rounds of 
replication to restore organ mass within a week after PH (Fausto, 2000; Kountouras et al., 2001). In the C57BL/6 mouse strain used in our studies, the first peak stage of S-phase was observed $48 \mathrm{~h}$ after $\mathrm{PH}$ and was followed by a smaller second peak $96 \mathrm{~h}$ after PH (Figure 4). We evaluated S-phase onset and progression in response to $\mathrm{PH}$ in $\mathrm{mTERC}^{+/+}$mice and $\mathrm{G}_{3} \mathrm{mTERC}^{-/-}$mice by BrdU pulse labeling (Figure 4A). In response to $\mathrm{PH}$, the timing of the
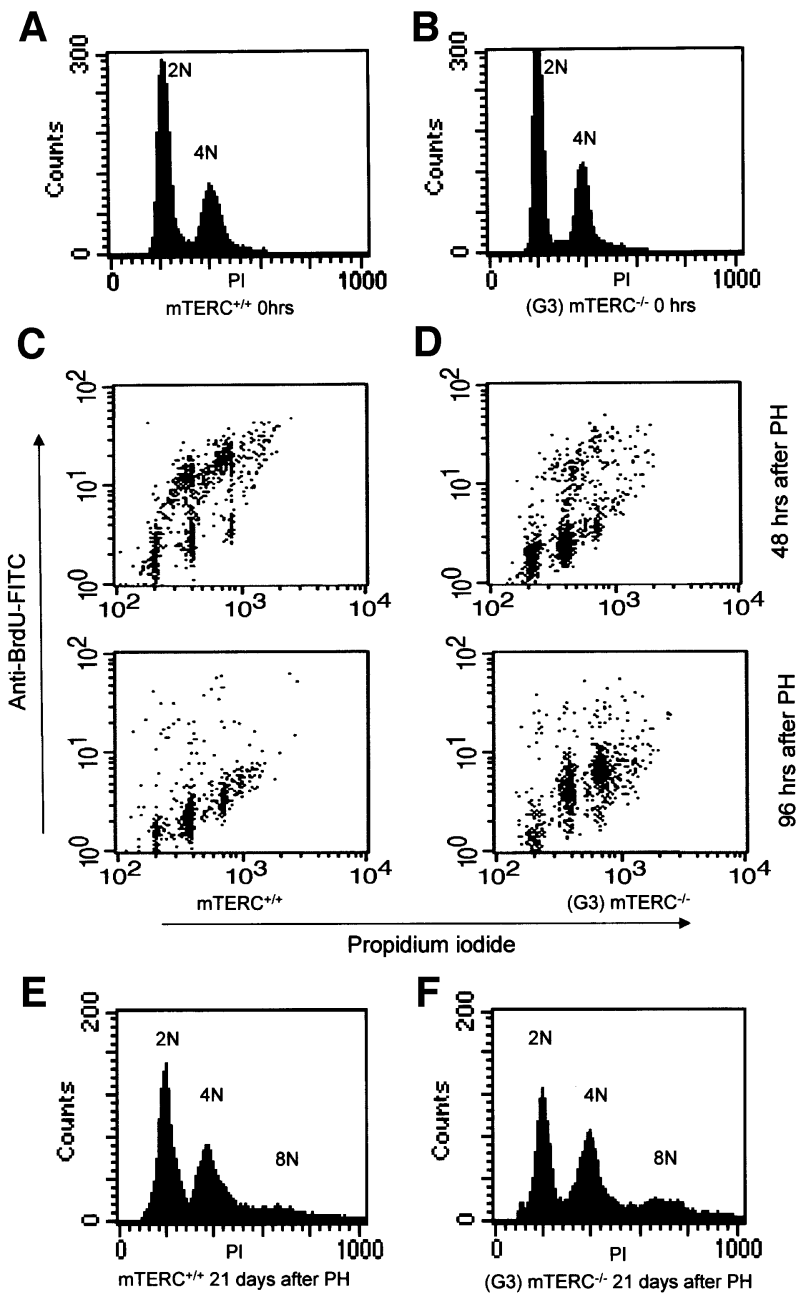

ropidium iodide

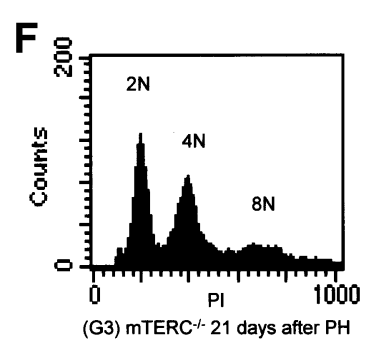

Fig. 5. Inhibition of S-phase entry, impaired $\mathrm{G}_{2} / \mathrm{M}$ progression and an additional round of cell division in regenerating liver of $\mathrm{G}_{3} \mathrm{mTERC}^{-/-}$ mice. (A-F) Representative photographs of one of the five independent flow cytometric analyses of liver nuclei at each time point from mTERC $^{+/+}$and $\mathrm{G}_{3}$ mTERC $^{-/-}$mice. (A and B) Ploidy distribution of cell nuclei from quiescent liver showing an almost similar composition of $2 \mathrm{~N}$ and $4 \mathrm{~N}$ nuclei in $\mathrm{mTERC}^{+/+}$and $\mathrm{G}_{3}$ mTERC $^{-/-}$mice. $(\mathbf{C}$ and D) Cell cycle profile of liver nuclei $48 \mathrm{~h}$ after $\mathrm{PH}$ (top panel) shows that a significantly lower number of $2 \mathrm{~N}(p=0.0031)$ and $4 \mathrm{~N}$ $(p=0.0219)$ nuclei are positive for BrdU in $\mathrm{G}_{3} \mathrm{mTERC}^{--}$than in mTERC $^{+/+}$mice, indicating that $G_{1} / S$ progression was inhibited in a subset of liver cells in $\mathrm{G}_{3}$ mTERC $^{-/-}$mice. In contrast, an increased number of $2 \mathrm{~N}(p=0.0516), 4 \mathrm{~N}(p=0.0005)$ and $8 \mathrm{~N}(p=0.0074)$ nuclei incorporate BrdU at $96 \mathrm{~h}$ (lower panel) after $\mathrm{PH}$ in $\mathrm{G}_{3} \mathrm{mTERC}^{-/-}$ than in $\mathrm{mTERC}^{+/+}$mice, indicating that a higher number of liver cells in $\mathrm{G}_{3}$ mTERC $^{-/-}$mice entered a second round of replication. Besides this difference in BrdU incorporation, there is an accumulation of cells with higher DNA content in $\mathrm{G}_{3}$ mTERC $^{-/}$mice during the time course of liver regeneration, indicating that $\mathrm{G}_{2} / \mathrm{M}$ progression was impaired. ( $\mathbf{E}$ and $\mathbf{F}$ ) Ploidy distribution of liver nuclei 21 days after $\mathrm{PH}$ again showing an almost similar DNA content in mTERC $^{+/+}$and $\mathrm{mTERC}^{-/-}$ $2 \mathrm{~N}(p=0.0683), 4 \mathrm{~N}(p=0.9831)$ and $8 \mathrm{~N}(p=0.0641)$, indicating partial rescue of $\mathrm{G}_{2} / \mathrm{M}$ arrest in the course of time. onset and the peak stages of S-phase were superimposable in mTERC $^{+/+}$and $\mathrm{G}_{3}$ mTERC $^{-/-}$mice. Nevertheless, the percentage of liver cells participating in the first round of replication was significantly lower in $\mathrm{G}_{3} \mathrm{mTERC}^{-/-}$mice than in $\mathrm{mTERC}^{+/+}$mice (Figure $4 \mathrm{~A}, \mathrm{~B}$ and D). In contrast, a significantly higher fraction of liver cells entered a second round of replication in $\mathrm{G}_{3} \mathrm{mTERC}^{-1-}$ mice than in mTERC $^{+/+}$mice (Figure 4A, C and E).

To test whether impaired S-phase entry would impact on organ regeneration and whether the elevated second round of replication could compensate for impaired regeneration, we followed the relative liver weight (liver weight/total body weight) of $\mathrm{mTERC}^{+/+}$and $\mathrm{G}_{3} \mathrm{mTERC}^{-/-}$ mice at different time points after PH. In parallel with the time course of S-phase, the liver weight of $\mathrm{G}_{3}$ mTERC $^{-/-}$ mice compared with mTERC $^{+/+}$mice was significantly decreased after the first round of replication, $72 \mathrm{~h}$ after $\mathrm{PH}$ (relative liver weight $2.27 \%$ in $\mathrm{G}_{3} \mathrm{mTERC}^{-/}$mice compared with $2.74 \%$ in mTERC $^{+/+}$mice, $p=0.001$ ). In agreement with our hypothesis that liver cells with sufficient telomere reserves accomplished organ regeneration in $\mathrm{G}_{3}$ mTERC $^{-/}$mice by entering a second round of replication, the liver weight was normalized in $G_{3}$ mTERC $^{-l-}$ mice after the second round of replication, $120 \mathrm{~h}$ after PH (data not shown). Similarly, the difference in total number of BrdU-labeled cells (after long-term labeling) between $\mathrm{G}_{3}$ mTERC $^{-/-}$and mTERC $^{+/+}$mice (Figure 1A and B) was significantly reduced after the second round of replication compared with the first round $(-4.69 \%, p=0.0274)$.

Together, our data indicated that impaired liver regeneration was due to inhibition of cell cycle re-entry in a subpopulation of cells with critically short telomeres in $\mathrm{G}_{3}$ mTERC $^{-/-}$mice but was compensated for by an additional round of replication by liver cells with sufficient telomere reserves capable of proliferation. An alternative explanation was that a subpopulation of resting liver cells in $G_{3}$ mTERC $^{-l-}$ mice was not in the $\mathrm{G}_{0}$ stage but was arrested in $\mathrm{G}_{2} / \mathrm{M}$, and was released from this block to exit mitosis and therefore re-entered the cell cycle at a delayed time point after PH. To test this possibility, cell cycle analysis was carried out by flow cytometry on resting and regenerating livers of $\mathrm{mTERC}^{+/+}$and $\mathrm{G}_{3} \mathrm{mTERC}^{-/-}$mice (Figure 5). Since in mouse liver a relatively high percentage of cells are binucleated, this analysis was carried out on cell nuclei, although cytospins on liver cells did not show a difference in the percentage of mononuclear (22.51 \pm 7.77 versus $25.66 \pm 3.83, p=0.2645)$ as well as binucleated $(76.99 \pm 8.90$ versus $74.32 \pm 3.82, p=0.395)$ cells in mTERC $^{+/+}$and $\mathrm{G}_{3}$ mTERC $^{-/-}$mice. In line with previous reports of flow cytometry on liver cell nuclei of several strains of mice (Severin et al., 1984; Danielsen et al., 1986), our study revealed that in addition to a cell population with a $2 \mathrm{~N}$ DNA content, a proportion of resting liver cell nuclei had a 4N DNA content. Cell cycle analysis of resting liver cell nuclei from $\mathrm{G}_{3} \mathrm{mTERC}^{-1-}$ and $\mathrm{mTERC}^{+/+}$mice revealed a similar distribution of nuclei with $2 \mathrm{~N}$ and $4 \mathrm{~N}$ DNA content in both groups (Table II; Figure $5 \mathrm{~A}$ and $\mathrm{B}$ ). In line with the BrdU staining data, the FACS analysis revealed that $48 \mathrm{~h}$ after $\mathrm{PH}$ the overall number of cells in S-phase was significantly lower in $\mathrm{G}_{3}$ mTERC $^{-/-}$than in mTERC $^{+/+}$mice (Table II; Figure 5C and $\mathrm{D}$, top panel). Interestingly, the suppression of S-phase 
Table II. Ploidy distribution and cell cycle profile of quiescent and proliferating liver cells at the indicated time points after PH in $\mathrm{mTERC}^{+/+}$and $\mathrm{G}_{3}$ mTERC $^{--}$as analyzed by flow cytometry

\begin{tabular}{|c|c|c|c|c|c|c|}
\hline Time & $2 \mathrm{~N}$ & $4 \mathrm{~N}$ & $8 \mathrm{~N}$ & 2N S-phase & 4N S-phase & 8N S-phase \\
\hline $\mathrm{mTERC}^{+/+} 0 \mathrm{~h}$ & $62.37 \pm 6.06$ & $37.6 \pm 6.03$ & - & - & - & - \\
\hline $\mathrm{G}_{3} \mathrm{mTERC}^{-/-} 0 \mathrm{~h}$ & $58.94 \pm 4.88$ & $41.09 \pm 4.93$ & - & - & - & - \\
\hline mTERC $^{+/+} 48 \mathrm{~h}$ after PH & $22.15 \pm 11.34$ & $26.75 \pm 7.53$ & $9.62 \pm 3.3$ & $11.93 \pm 5.73$ & $21.3 \pm 10.6$ & $8.15 \pm 3.33$ \\
\hline $\mathrm{G}_{3}$ mTERC $^{-1-} 48 \mathrm{~h}$ after $\mathrm{PH}$ & $23.42 \pm 9.26$ & $44.76 \pm 11.12$ & $17 \pm 7.31$ & $1.76 \pm 0.84$ & $8.15 \pm 1.47$ & $4.73 \pm 1.34$ \\
\hline $\mathrm{mTERC}^{+/+} 96 \mathrm{~h}$ after $\mathrm{PH}$ & $43.18 \pm 17.25$ & $40.87 \pm 13.46$ & $10.98 \pm 7.77$ & $1.58 \pm 0.83$ & $1.49 \pm 1.13$ & $1.36 \pm 1.13$ \\
\hline $\mathrm{G}_{3} \mathrm{mTERC}^{-1-} 96 \mathrm{~h}$ after $\mathrm{PH}$ & $20.14 \pm 6.42$ & $43.26 \pm 8.68$ & $25.46 \pm 9.86$ & $2.84 \pm 1.02$ & $4.41 \pm 0.62$ & $4.05 \pm 1.29$ \\
\hline $\mathrm{mTERC}^{+/+} 21$ days after $\mathrm{PH}$ & $49.93 \pm 2.64$ & $42.97 \pm 2.79$ & $6.24 \pm 1.33$ & - & - & - \\
\hline $\mathrm{G}_{3}$ mTERC $^{-/-} 21$ days after $\mathrm{PH}$ & $42.89 \pm 0.72$ & $42.92 \pm 1.68$ & $14.43 \pm 2.77$ & - & - & - \\
\hline
\end{tabular}

entry in $\mathrm{G}_{3}$ mTERC $^{-/-}$mice affected cells with $2 \mathrm{~N}, 4 \mathrm{~N}$ and higher DNA content. Although it cannot be excluded that some of the $4 \mathrm{~N}$ and $8 \mathrm{~N}$ cells were arrested at the $\mathrm{G}_{2} / \mathrm{M}$ stage of the cell cycle, the inhibition of S-phase entry from $2 \mathrm{~N}$ cells indicated that suppressed S-phase entry in $\mathrm{G}_{3}$ mTERC $^{-/}$was at least in part due to a pre-S-phase arrest.

As anticipated from the BrdU staining results (Figure 4), FACS analysis at $96 \mathrm{~h}$ after $\mathrm{PH}$ revealed a higher percentage of liver cells in S-phase in $\mathrm{G}_{3}$ mTERC $^{-/}$than in mTERC $^{+/+}$mice (Table II; Figure $5 \mathrm{C}$ and D, bottom panel). The fact that this S-phase entry predominantly derived from cells with $4 \mathrm{~N}$ and $8 \mathrm{~N}$ DNA content suggested that the second peak of S-phase in $\mathrm{G}_{3}$ mTERC $^{-/-}$mice did not result from $4 \mathrm{~N}$ cells overcoming a $\mathrm{G}_{2} / \mathrm{M}$ block to reenter S-phase from a $2 \mathrm{~N}$ stage after completion of mitosis.

In addition to the above data on S-phase entry, the FACS analysis revealed an accumulation of cells with higher DNA content in $\mathrm{G}_{3}$ mTERC $^{-/-}$compared with mTERC $^{+/+}$mice in the time course of liver regeneration following PH. These data are in line with previous reports of an impaired $\mathrm{G}_{2} / \mathrm{M}$ progression of regenerating liver cells in mTERC ${ }^{-l-}$ mice (Rudolph et al., 2000). Cell cycle analysis 21 days after $\mathrm{PH}$ again revealed an almost similar ploidy distribution in $\mathrm{mTERC}^{+/+}$and $\mathrm{G}_{3} \mathrm{mTERC}^{-/-}$mice (Figure $5 \mathrm{E}$ and $\mathrm{F}$ ), indicating that impaired $\mathrm{G}_{2} / \mathrm{M}$ progression in $\mathrm{G}_{3}$ mTERC $^{-/-}$was either temporary or associated with decreased cell survival over time.

\section{Discussion}

Our current study demonstrates that telomere shortening at the cellular level affects organ regeneration in vivo by inhibiting a subpopulation of cells with critically short telomeres from entering the cell cycle, thereby limiting the pool of proliferating cells within an organ system. As a result, there is an elevated regenerative pressure on the proliferating subpopulation of cells to compensate for impaired organ regeneration by additional rounds of cell division, which in turn accelerates the rate of telomere shortening and the imbalance of proliferating and nonproliferating cells. Our results are further strengthened by previous studies in $\mathrm{mTERC}^{-/-}$mice showing that it is not the average telomere length but the prevalence of critically short telomeres that leads to regenerative disorders (Hemann et al., 2001). The new concept derived from our study is that the prevalence of critically short telomeres at the cellular level determines the proliferative capacity of cells within an organ system. Thus, the regenerative capacity of organs and tissues depends on the size of the population of cells with sufficient telomere reserves required for cell proliferation.

Which mechanism limits cell proliferation in the subpopulation of cells with critically short telomeres? We show that mitogen signaling and apoptosis do not contribute to impaired liver regeneration in response to telomere shortening in our model system of PH. It seems likely that the lack of telomere-directed apoptosis reflects the modest regenerative stress induced by $\mathrm{PH}$ since we have previously shown that critical telomere shortening induces prominent hepatocyte apoptosis during clonal expansion of hepatocytes following acute liver failure-a setting of potent regenerative stress. The prevalence of $\beta$-galactosidase-positive cells and the coincidence of $\beta$-galactosidase activity with non-proliferating cells indicate that the cells with critically short telomeres have reached the senescence stage. In line with this hypothesis, gene expression profiling and RT-PCR analysis of regenerating liver at the onset of S-phase revealed an upregulation of downstream targets of p53 (Table I) - a pathway critical for inducing cellular senescence in response to telomere shortening (Vaziri and Benchimol, 1996; Chin et al., 1999; Smogorzewska and de Lange, 2002).

At which stage of the cell cycle are the liver cells arrested? Previous studies in $\mathrm{mTERC}^{-/-}$mice have revealed that telomere shortening induces a biphasic cell cycle block in mouse embryonic fibroblasts (Chin et al., 1999) and impaired mitotic progression in regenerating liver (Rudolph et al., 2000). In line with these studies, our current data on liver regeneration following $\mathrm{PH}$ show impaired cell cycle progression at two stages: pre-S-phase and $\mathrm{G}_{2} / \mathrm{M}$. Impaired S-phase entry in $\mathrm{G}_{3}$ mTERC $^{-/-}$mice was independent of the DNA content of the cells, demonstrating that $\mathrm{G}_{1} / \mathrm{S}$ progression was impaired, and the accumulation of cells with higher DNA ploidy in $\mathrm{G}_{3}$ mTERC $^{-/-}$mice during the time course of liver regeneration indicated that $\mathrm{G}_{2} / \mathrm{M}$ progression was impaired. We hypothesize that if telomeres are dysfunctional in resting cells, cell cycle re-entry is inhibited at the $\mathrm{G}_{1} / \mathrm{S}$ transition. In addition, some cells will acquire dysfunctional telomeres during S-phase owing to further telomere shortening during DNA replication and will consequently be withdrawn from the cell cycle at the $\mathrm{G}_{2} / \mathrm{M}$ stage.

Our study supports a model in which inhibition of cell cycle entry in a subpopulation of cells with critically short telomeres results in delayed organ regeneration by requiring an additional round of replication by cells with sufficient telomere reserves. According to this model, 
regenerative defects are determined by the size of the proliferating population of cells within an organ system necessary to maintain organ function and homeostasis. It seems likely that the differences in telomere length between individual cells within an organ reflect the replicative history of cells during organogenesis and postnatal life. In addition, other factors that possibly affect telomere length might be differences in metabolic rates and intracellular load of radical oxygen species. The percentage of liver cells inhibited from cell cycle re-entry in $\mathrm{G}_{3} \mathrm{mTERC}^{-/-}$mice in our study was $\sim 15 \%$; most of them $(\sim 11 \%)$ in turn show $\beta$-galactosidase activity. The mice do not show any liver phenotype during development and aging, but show an accelerated onset of cirrhosis in response to chronic organ damage (S.U.Wiemann and K.L.Rudolph, unpublished data) similar to the results obtained from $\mathrm{G}_{6}$ mTERC $^{-/-}$mice in a mixed genetic background (Rudolph et al., 2000). Therefore, the relatively small percentage of senescent cells inhibited from cell cycle re-entry seems to allow normal organ homeostasis in normal conditions, but under circumstances of elevated cell turnover it leads to impaired organ homeostasis.

Does the telomere hypothesis of impaired organ regeneration in mouse models apply to humans? To date there is an accumulation of correlative data indicating that telomere shortening might impact on the regenerative capacity of human tissues during aging and chronic diseases. In addition, mutation of the essential RNA component of human telomerase has been implicated in premature aging, bone marrow failure and liver cirrhosis among other phenotypes in patients with dyskeratosis congenita (Vulliamy et al., 2001). Interestingly, in human cirrhosis, the prevalence of senescent hepatocytes ranges from 2 to $15 \%$ in the vast majority of cases, indicating that cellular senescence at rates similar to those observed in our study impairs regular organ regeneration in chronic liver disease in humans (Wiemann et al., 2002). Determination of the rates of cellular senescence and the identification of new markers of senescence could be useful to test the relevance of senescence in limiting the regenerative capacity in different human tissues and organs during aging and chronic disease.

\section{Materials and methods}

\section{Mice}

Male mTERC $^{-/-}$and littermate mTERC $^{+/+}$control mice (age 1012 weeks) in a C57/B6J background were used for this study. The mice were bred and maintained in the animal facility, Medical School Hannover, Germany, on a standard diet.

\section{Partial hepatectomy and BrdU labeling}

All the mice were operated on in the morning (between 8.00 and 11.00 a.m.) as described (Higgins and Anderson, 1931). Mice were anesthetized and subjected to $70 \%$ PH by surgically removing the left lateral, left median and right median lobes without disrupting the portal vein, biliary tract and gallbladder. The mice were killed from each group $\left(\mathrm{mTERC}^{+/+}\right.$and $\left.\mathrm{mTERC}^{-/-}\right)$at $24 \mathrm{~h}(n=3), 36 \mathrm{~h}(n=3), 48 \mathrm{~h}(n=5), 72 \mathrm{~h}$ $(n=5), 96 \mathrm{~h}(n=5)$ and $120 \mathrm{~h}(n=5)$ after PH. Ten microliters per gram body weight of labeling reagent $[10: 1$ ratio, BrdU and 5-fluoro20-deoxyuridine (Cell Proliferation Kit, Amersham)] were administered to the animals intraperitoneally $2 \mathrm{~h}$ before killing. For continuous labeling of all the proliferating cells, $0.8 \mathrm{mg} / \mathrm{ml} \mathrm{BrdU}$ (Sigma) was given in sterile drinking water and fresh water was prepared every $24 \mathrm{~h}$. To increase the sensitivity of the continuous labeling procedure, $200 \mu \mathrm{l}$ of $1 \mathrm{mg} / \mathrm{ml} \mathrm{BrdU}$ in phosphate-buffered saline (PBS) were administered intraperitoneally at $12 \mathrm{~h}$ intervals between 24 and $72 \mathrm{~h}$ (or $120 \mathrm{~h}$ ) after PH. After killing, the liver lobes were snap frozen in liquid nitrogen and stored at $-80^{\circ} \mathrm{C}$ until required for further analysis.

\section{Immunohistochemical detection of BrdU}

After fixation of $7 \mu \mathrm{m}$ cryostat sections in ice-cold acetone-methanol (1:1) for $10 \mathrm{~min}$, samples were washed in Tris-buffered saline (TBS)Tween, dehydrated in $70 \%$ ethanol for $30 \mathrm{~min}$ and air dried. Endogenous peroxidase activity was blocked by $3 \% \mathrm{H}_{2} \mathrm{O}_{2}$ in methanol for $10 \mathrm{~min}$, followed by two $5 \mathrm{~min}$ washes in TBS-Tween, denaturation in alkaline formamide $(95 \mathrm{ml}$ formamide $+5 \mathrm{ml} 1 \mathrm{~N} \mathrm{NaOH})$ for $30 \mathrm{~s}$ at $70^{\circ} \mathrm{C}$, washing for $5 \mathrm{~min}$ in TBS-Tween at $70^{\circ} \mathrm{C}$ and incubation in $15 \mathrm{mM}$ tri-sodium citrate in formamide for $15 \mathrm{~min}$ at $70^{\circ} \mathrm{C}$. The reaction was stopped by washing the slides in ice-cold TBS-Tween twice for 5 min each. A second fixation was carried out in 3\% formaldehyde in PBS for $30 \mathrm{~min}$, followed by two $5 \mathrm{~min}$ washes in TBS-Tween and incubation in $0.2 \%$ glutaraldehyde in PBS for $10 \mathrm{~min}$ at room temperature. The slides were then washed twice for $5 \mathrm{~min}$ in TBS-Tween and incubated with anti$\mathrm{BrdU}$ monoclonal antibody overnight at $4^{\circ} \mathrm{C}$ in a wet chamber. After two washes with TBS-Tween, the slides were incubated with a peroxidaselabeled anti-mouse IgG2a secondary antibody for $30 \mathrm{~min}$ at room temperature, followed by three $5 \mathrm{~min}$ washes, and detection was performed by incubating them with the substrate $3,3^{\prime}$-diaminobenzidine tetrahydrochloride (DAB) $(25 \mathrm{mg}$ of DAB, $100 \mu \mathrm{l}$ of substrate intensifier, $50 \mathrm{ml}$ of PBS) for $20 \mathrm{~min}$, followed by two $5 \mathrm{~min}$ washes with doubledistilled water. The slides were then counterstained with hemalum solution, mounted with mounting medium and stored in the dark until analysis. A BrdU-labeling index was determined by counting the number of BrdU-positive cells randomly in 20 low-power magnification fields $(10 \times)$ and expressing the number of BrdU-labeled nuclei as a percentage of all nuclei counted.

\section{Senescence-associated $\beta$-galactosidase staining}

Senescence-associated $\beta$-galactosidase staining was carried out as described previously (Dimri et al., 1995). All the samples were stained in triplicate. Analysis was carried out in blinded fashion. The number of SA $\beta$-galactosidase-positive cells was counted randomly in 20 low-power fields $(10 \times)$ and expressed as a percentage of all cells counted.

\section{BrdU-telomere probe co-staining}

Cryostat sections $(7 \mu \mathrm{m})$ were fixed, dehydrated and denatured exactly as described above. Following the second fixation in 3\% formaldehyde in PBS, the tissues were digested with acidified pepsin (100 mg of pepsin, $100 \mathrm{ml}$ of $\mathrm{H}_{2} \mathrm{O}, 84 \mu \mathrm{l}$ of conc. $\mathrm{HCl}$ ) for $10 \mathrm{~min}$, followed by two $5 \mathrm{~min}$ washes in TBS-Tween. Then they were fixed by incubating in $0.2 \%$ glutaraldehyde in PBS for $10 \mathrm{~min}$ at room temperature. The slides were co-incubated with anti-BrdU monoclonal antibody (Amersham) and telomere probe hybridization mix [250 $\mu$ l final volume: $2.5 \mu 1$ of $1 \mathrm{M}$ Tris-HCl pH 7.2, $21.4 \mu \mathrm{l}$ of $\mathrm{MgCl}_{2}\left(25 \mathrm{mM} \mathrm{MgCl}_{2}, 9 \mathrm{mM}\right.$ citric acid, $\left.82 \mathrm{mM} \mathrm{Na}_{2} \mathrm{HPO}_{4} \mathrm{pH} 7.4\right), 175 \mu \mathrm{l}$ of deionized formamide, $12.5 \mu \mathrm{l}$ of $10 \%$ (w/w) blocking reagent, $5 \mu \mathrm{l}$ of $25 \mu \mathrm{g} / \mathrm{ml}$ PNA Cy3-telomere probe, $33.6 \mu 1$ of $\mathrm{H}_{2} \mathrm{O}$ ] overnight at $4^{\circ} \mathrm{C}$ in a wet chamber. Then they were given three $5 \mathrm{~min}$ washes with TBS-Tween and incubated with FITCconjugated goat anti-mouse IgG secondary antibody (Dako) for $30 \mathrm{~min}$ at room temperature, followed by three 5 min washes in TBS-Tween and mounting in DAPI mounting solution. The telomere fluorescence intensities were calibrated as described (Herrera et al., 1999; Wiemann et al., 2002). Quantification of the telomere fluorescence intensity was performed on cy 3 and DAPI images captured at a magnification of $100 \times$ using TFL-TELO V1.0, a telomere analysis program developed by P.Landsdorp.

\section{Senescence-BrdU co-staining}

For simultaneous detection of senescence and cell proliferation in the same sample, first SA $\beta$-galactosidase staining at $\mathrm{pH} 6$ was carried out (as described above $)$ on $7 \mu \mathrm{m}$ sections of liver samples from $\mathrm{mTERC}^{+/+}(n=$ $5)$ and mTERC $^{--}(n=5)$, followed by BrdU staining as described above.

\section{Senescence-telomere probe co-staining}

To measure the telomere lengths in senescent cells and proliferating cells in the same sample, first SA $\beta$ galactosidase staining was carried out (as described above), followed by telomere probe hybridization (as described above), except that the pepsin digestion step was optimized to $7 \mathrm{~min}$ to detect cytoplasmic senescent staining and at the same time to minimize background for telomere fluorescence intensity measurement. 


\section{Apoptosis staining}

The tunnel assay was performed on cryostat sections according to the manufacturer's protocol (In Situ Cell Death Detection Kit, Roche). The number of apoptotic cells was counted in 20 high-power fields $(100 \times)$. All the counts were performed without knowledge of the day(s) after PH.

\section{Determination of IL-6 serum levels}

Sera were obtained from partially hepatectomized mice at 1, 3,6,9 and $12 \mathrm{~h}$, and stored at $-80^{\circ} \mathrm{C}$ before testing. Serum IL-6 levels were determined using the Pharmingen OptEIA ${ }^{\mathrm{TM}}$ Set: Mouse IL-6 kit according to the manufacturer's protocol.

\section{Liver perfusion, nuclei preparation and flow cytometry}

Liver cells were collected by the collagenase perfusion method. The cells were collected from the quiescent liver (non-operated) $(n=5)$ and $48 \mathrm{~h}$ $(n=6), 96 \mathrm{~h}(n=5)$ and 21 days $(n=4)$ after PH from each group $\left(\mathrm{mTERC}^{+/+}\right.$and $\left.\mathrm{mTERC}^{-/-}\right)$. Mice were anesthetized and subjected to $70 \% \mathrm{PH}$, and $10 \mu \mathrm{l} / \mathrm{g}$ body weight labeling reagent [10:1 ratio of 5-BrdU and 5-fluoro-20-deoxyuridine (Cell Proliferation Kit, Amersham)] was administered $2 \mathrm{~h}$ before liver perfusion. The liver was perfused through the portal vien by inserting a SURFLO I.V catheter connected to an ISMATEC pump with KRBI buffer $(150 \mathrm{mM} \mathrm{NaCl}, 5 \mathrm{mM} \mathrm{KCl}, 5 \mathrm{mM}$ glucose, $25 \mathrm{mM} \mathrm{NaHCO}_{3}, 20 \mathrm{mM}$ HEPES, $1 \mathrm{mM}$ EDTA pH 7.4 at $37^{\circ} \mathrm{C}$ ) until the blood was completely drained out, followed by KRBII $(150 \mathrm{mM}$ $\mathrm{NaCl}, 5 \mathrm{mM} \mathrm{KCl}, 5 \mathrm{mM}$ glucose, $25 \mathrm{mM} \mathrm{NaHCO}{ }_{3}, 20 \mathrm{mM}$ HEPES, $0.5 \mathrm{mM} \mathrm{CaCl}, 0.5 \mathrm{mg} / \mathrm{ml}$ collagenase at $37^{\circ} \mathrm{C}$ ) until the liver mass became soft and fragile. The liver mass was suspended in $10 \mathrm{ml}$ of PBS by gentle pipetting and then centrifuged at $50 \mathrm{~g}$ for $3 \mathrm{~min}$ for hepatocyte purification.

Next, $1 \times 10^{6}$ cells were suspended gently for 2 min without producing air bubbles in $2 \mathrm{ml}$ of NPBT buffer $(10 \mathrm{mM}$ Tris- $\mathrm{HCl} \mathrm{pH} \mathrm{7.4,} 2 \mathrm{mM}$ $\mathrm{MgCl}_{2}, 140 \mathrm{mM} \mathrm{NaCl}, 0.5 \%$ Triton X-100) and centrifuged through a $50 \%$ sucrose gradient $(50 \%$ sucrose in NPB, $10 \mathrm{mM}$ Tris- $\mathrm{HCl} \mathrm{pH} 7.4$, $2 \mathrm{mM} \mathrm{MgCl} 2,140 \mathrm{mM} \mathrm{NaCl}$ ) for $10 \mathrm{~min}$ at 13000 r.p.m. The nuclear pellet was resuspended in a suitable volume of PBS and again centrifuged at $50 \mathrm{~g}$ for $2 \mathrm{~min}$ to remove non-lysed cells. The pure nuclei obtained from this procedure were used for flow cytometry. The nuclei collected $0 \mathrm{~h}$ and 21 days after PH were stained with PI only, whereas the nuclei collected 48 and $96 \mathrm{~h}$ after PH were double stained with PI and FITC-antiBrdU antibody (Becton Dickinson) according to the manufacturer's instructions. Flow cytometric analysis was carried out with a FACScan (Becton Dickinson) equipped with Cellquest software.

\section{RNA extraction and cDNA synthesis}

The total RNA was extracted according to the manufacturer's protocol (RNA Clean ${ }^{\mathrm{TM}}$; Hybaid). The RNA extracted from the liver samples at $0 \mathrm{~h}$ $\left[\mathrm{mTERC}^{+/+}(n=6), \mathrm{mTERC}^{-/-}(n=5)\right]$ and at $30-36 \mathrm{~h}$ after PH $\left[\mathrm{mTERC}^{+/}\right.$ ${ }^{+}(n=12)$ and mTERC $\left.^{-/-}(n=10)\right]$ and the RNA with an $\mathrm{OD}_{260 / 280}$ ratio of 2 or more was used for microarray, cDNA synthesis and quantitative realtime PCR. Two micrograms of total RNA were used to synthesize cDNA with oligo-dT primer and Superscript II-RT enzyme (Invitrogen). The RT reaction was checked by amplifying a 130 bp fragment of the housekeeping gene $R S P$ 9.

\section{DNA microarray hybridization and analysis}

The quality and integrity of the total RNA were checked by running all the samples on an Agilent Technologies 2100 Bioanalyzer (Agilent Technologies). The expression analysis was carried out according to the manufacturer's standard protocols (Affymetrix GeneChip Expression Analysis Manual; Affymetrix). A detailed description of the experimental set-up and the data analysis is accessible online (www.gbf.de/array) under downloads (under Satyanarayana et al.: ExperimentalDesign). The full dataset is accessible on the same web page under Table1 (full data set on signal intensities) and Table2 (conclusive data set on calculated gene expression changes).

\section{Quantitative real-time PCR}

Quantitative real-time PCR was performed on an ABI prism 7700 Sequence detection system (PE Applied Biosystems) using SYBR Green I as a double-strand DNA-specific binding dye. The same RNA preparations were used for microarray and quantitative RT-PCR. All the samples were analyzed in triplicate and the expression of each target gene was confirmed by three independent PCR runs. The cycle profile of PCR is as follows: an initial 10 min activation of Hot Star Taq ${ }^{\mathrm{TM}}$ DNA polymerase (Qiagen) at $95^{\circ} \mathrm{C}$, followed by denaturation at $94^{\circ} \mathrm{C}$ for $15 \mathrm{~s}$, annealing at $54^{\circ} \mathrm{C}$ for $15 \mathrm{~s}$ and extension at $72^{\circ} \mathrm{C}$ for $30 \mathrm{~s}$. Forty cycles of PCR amplification were performed to confirm the expression levels of eight selected target genes, and the housekeeping gene $R S P 9$ was used as an internal control to normalize the expression levels; the $\mathrm{Ct}$ for the target genes appears between 24 and 30 cycles. The quantification data were analyzed with the ABI Prism 7700 analysis software.

\section{Statistical programs}

Student's $t$-test, Fisher's exact test and Graphpad InStat software were used to calculate the statistical significance and standard deviations.

\section{Acknowledgements}

This paper is dedicated to the memory of Jo Lauber. We thank Professor Ungewickell for the fluorescence microscopy, and Dr R.Greenberg and Dr H.Sundberg for critical reading of the manuscript. K.L.R. is supported by grants from the Deutsche Forschungsgemeinschaft (Ru 745/2-1) and Deutsche Krebshilfe e.V. (10-1809-Ru1), M.A.B. is supported by grants from the Spanish Ministry of Science and Technology, the European Union and the Department of Immunology and Oncology (CSICPharmacia Corporation).

\section{References}

Allsopp,R.C. and Harley,C.B. (1995) Evidence for a critical telomere length in senescent human fibroblasts. Exp. Cell Res., 219, 130-136.

Allsopp,R.C., Chang,E., Kashefi-Aazam,M., Rogaev,E.I., Piatyszek,M.A., Shay,J.W. and Harley,C.B. (1995) Telomere shortening is associated with cell division in vitro and in vivo. Exp. Cell Res., 220, 194-200.

Ball,S.E., Gibson,F.M., Rizzo,S., Tooze,J.A., Marsh,J.C. and GordonSmith,E.C. (1998) Progressive telomere shortening in aplastic anemia. Blood, 91, 3582-3592.

Blackburn,E.H. (1991) Structure and function of telomeres. Nature, 350, 569-573.

Blasco,M.A., Lee,H.W., Hande,M.P., Samper,E., Lansdorp,P.M., DePinho,R.A. and Greider,C.W. (1997) Telomere shortening and tumor formation by mouse cells lacking telomerase RNA. Cell, 91, 25-34.

Bodnar,A.G. et al. (1998) Extension of life-span by introduction of telomerase into normal human cells. Science, 279, 349-352.

Bond,J., Haughton,M., Blaydes,J., Gire,V., Wynford-Thomas,D. and Wyllie,F. (1996) Evidence that transcriptional activation by p53 plays a direct role in the induction of cellular senescence. Oncogene, 13, 2097-2104.

Boultwood,J., Peniket,A., Watkins,F., Shepherd,P., McGale,P., Richards,S., Fidler,C., Littlewood,T.J. and Wainscoat,J.S. (2000) Telomere length shortening in chronic myelogenous leukemia is associated with reduced time to accelerated phase. Blood, 96, 358361 .

Bringold,F. and Serrano,M. (2000) Tumor suppressors and oncogenes in cellular senescence. Exp. Gerontol., 35, 317-329.

Chang,E. and Harley,C.B. (1995) Telomere length and replicative aging in human vascular tissues. Proc. Natl Acad. Sci. USA, 92, 1119011194.

Chen,K.Y. (1997) Transcription factors and the down-regulation of $\mathrm{G}_{1} / \mathrm{S}$ boundary genes in human diploid fibroblasts during senescence. Front. Biosci., 2, 417-426.

Chin,L., Artandi,S.E., Shen,Q., Tam,A., Lee,S.L., Gottlieb,G.J., Greider,C.W. and DePinho,R.A. (1999) p53 deficiency rescues the adverse effects of telomere loss and cooperates with telomere dysfunction to accelerate carcinogenesis. Cell, 97, 527-538.

Cressman,D.E., Greenbaum,L.E., DeAngelis,R.A., Ciliberto,G., Furth,E.E., Poli,V. and Taub,R. (1996) Liver failure and defective hepatocyte regeneration in interleukin-6 deficient mice. Science, 274, 1379-1383.

Danielsen,H., Lindmo,T. and Reith,A. (1986) A method for determining ploidy distributions in liver tissue by stereological analysis of nuclear size calibrated by flow cytometric DNA analysis. Cytometry, 7, 475480.

Dimri,G.P. et al. (1995) A biomarker that identifies senescent human cells in culture and in aging skin in vivo. Proc. Natl Acad. Sci. USA, 92, 9363-9367.

Dulic,V., Beney,G.E., Frebourg,G., Drullinger,L.F. and Stein,G.H. (2000) Uncoupling between phenotypic senescence and cell cycle arrest in aging p21-deficient fibroblasts. Mol. Cell. Biol., 20, 67416754. 
Effros,R.B. (2000) Telomeres and HIV disease. Microbes Infect., 2, $69-76$.

Fausto,N. (2000) Liver regeneration. J. Hepatol., 32, 19-31.

Gonzalez-Suarez,E., Samper,E., Flores,J.M. and Blasco,M.A. (2000) Telomerase-deficient mice with short telomeres are resistant to skin tumorigenesis. Nat. Genet., 26, 114-117.

Harley,C.B., Futcher,A.B. and Greider,C.W. (1990) Telomeres shorten during ageing of human fibroblasts. Nature, 345, 458-460.

Hemann,M.T., Strong,M.A., Hao,L.Y. and Greider,C.W. (2001) The shortest telomere, not average telomere length, is critical for cell viability and chromosome stability. Cell, 107, 67-77.

Herrera,E., Samper,E., Martin-Caballero,J., Flores,J.M., Lee,H.W. and Blasco,M.A. (1999) Disease states associated with telomerase deficiency appear earlier in mice with short telomeres. EMBO J., 18, 2950-2960.

Higgins,G.M. and Anderson,R.M. (1931) Experimental pathology of the liver. I. Restoration of the liver of the white rat following partial surgical removal. Arch. Pathol., 12, 186-202.

Jarrard,D.F. et al. (1999) p16/pRb pathway alterations are required for bypassing senescence in human prostate epithelial cells. Cancer Res., 59, 2957-2964.

Kinouchi,Y., Hiwatashi,N., Chida,M., Nagashima,F., Takagi,S., Maekawa,H. and Toyota,T. (1998) Telomere shortening in the colonic mucosa of patients with ulcerative colitis. J. Gastroenterol., 33, 343-348

Kitada,T., Seki,S., Kawakita,N., Kuroki,T. and Monna,T. (1995) Telomere shortening in chronic liver diseases. Biochem. Biophys. Res. Commun., 211, 33-39.

Kountouras,J., Boura,P., Lygidakis,N.J. (2001) Liver regeneration after hepatectomy. Hepatogastroenterology, 48, 556-562.

Lee,H.W., Blasco,M.A., Gottlieb,G.J., Horner,J.W., 2nd, Greider,C.W. and DePinho,R.A. (1998) Essential role of mouse telomerase in highly proliferative organs. Nature, 392, 569-574.

Li,W., Liang,X., Leu,J.I., Kovalovich,K., Ciliberto,G. and Taub,R. (2001) Global changes in interleukin-6-dependent gene expression patterns in mouse livers after partial hepatectomy. Hepatology, 33, 1377-1386.

Lindsey,J., McGill,N.I., Lindsey,L.A., Green,DK. and Cooke,H.J. (1991) In vivo loss of telomeric repeats with age in humans. Mutat. Res., 256, $45-48$.

Pang,J.H. and Chen,K.Y. (1994) Global change of gene expression at late $\mathrm{G}_{1} / \mathrm{S}$ boundary may occur in human IMR-90 diploid fibroblasts during senescence. J. Cell. Physiol., 160, 531-538.

Paradis,V., Youssef,N., Dargere,D., Ba,N., Bonvoust,F., Deschatrette,J. and Bedossa,P. (2001) Replicative senescence in normal liver, chronic hepatitis $\mathrm{C}$ and hepatocellular carcinomas. Hum. Pathol., 32, 327-332.

Poon,S.S. and Lansdorp,P.M. (2001) Current Protocols in Cell Biology. Wiley, New York, NY, pp. 18.4.1-18.4.21.

Rudolph,K.L., Chang,S., Lee,H.-W., Blasco,M., Gottlieb,G.J., Greider,C. and DePinho,R.A. (1999) Longevity, stress response and cancer in aging telomerase deficient mice. Cell, 96, 701-712.

Rudolph,K.L., Chang,S., Millard,M., Schreiber-Agus,N. and DePinho,R.A. (2000) Inhibition of experimental liver cirrhosis in mice by telomerase gene delivery. Science, 287, 1253-1258.

Samper,E., Flores,J.M. and Blasco M.A. (2001) Restoration of telomerase activity rescues chromosomal instability and premature aging in $\mathrm{Terc}^{-/-}$mice with short telomeres. EMBO Rep., 2, 800-807.

Serrano,M., Lin,A.W., McCurrach,M.E., Beach,D. and Lowe,S.W. (1997) Oncogenic ras provokes premature cell senescence associated with accumulation of p53 and p16INK4a. Cell, 88, 593-602.

Severin,E., Willers,R. and Bettecken,T. (1984) Flow cytometric analysis of mouse hepatocyte ploidy. II.The development of polyploidy pattern in four mice strains with different life spans. Cell Tissue Res., 238, 649-652.

Severino,J., Allen,R.G., Balin,S., Balin,A. and Cristofalo,V.J. (2000) Is $\beta$-galactosidase staining a marker of senescence in vitro and in vivo? Exp. Cell Res., 257, 162-171.

Shay,J.W., Pereira-Smith,O.M. and Wright,W.E. (1991) A role for both $\mathrm{RB}$ and 553 in the regulation of human cellular senescence. Exp. Cell Res., 196, 33-39.

Smogorzewska,A. and de Lange,T (2002) Different telomere damage signaling pathways in human and mouse cells. EMBO J., 21, 43384348.

Vairapandi,M., Balliet,A.G., Hoffman,B. and Liebermann,D.A. (2002) GADD45b and GADD45g are cdc2/cyclinB1 kinase inhibitors with a role in $\mathrm{S}$ and $\mathrm{G}_{2} / \mathrm{M}$ cell cycle checkpoints induced by genotoxic stress. J. Cell. Physiol., 192, 327-338.
Vaziri,H. and Benchimol,S. (1996) From telomere loss to p53 induction and activation of a DNA-damage pathway at senescence: the telomere loss/DNA damage model of cell aging. Exp. Gerontol., 31, 295-301.

Vaziri,H., Schachter,F., Uchida,I., Wei,L., Zhu,X., Effros,R., Cohen,D. and Harley,C.B. (1993) Loss of telomeric DNA during aging of normal and trisomy 21 human lymphocytes. Am. J. Hum. Genet., 52, 661-667.

Vaziri,H., Dragowska,W., Allsopp,R.C., Thomas,T.E., Harley,C.B. and Lansdorp,P.M. (1994) Evidence for a mitotic clock in human hematopoietic stem cells: loss of telomeric DNA with age. Proc. Natl Acad. Sci. USA, 91, 9857-9860.

Vulliamy,T., Marrone,A., Goldman,F., Dearlove,A., Bessler,M., Mason,P.J. and Dokal,I. (2001) The RNA component of telomerase is mutated in autosomal dominant dyskeratosis congenita. Nature, 413, 432-435.

Wiemann,S.U. et al. (2002) Hepatocyte telomere shortening and senescence are general markers of human liver cirrhosis. FASEB J., 16, 935-942.

Wright,W.E. and Shay,J.W. (1992) The two-stage mechanism controlling cellular senescence and immortalization. Exp. Gerontol., 27, 383-389.

Yu,G.L., Bradley,J.D., Attardi,L.D. and Blackburn,E.H. (1990) In vivo alteration of telomere sequences and senescence caused by mutated Tetrahymena telomerase RNAs. Nature, 344, 126-132.

Received September 2, 2002; revised May 21, 2003; accepted June 2, 2003 